\title{
Conceptual Analysis of Sustainability and Sustainable Development
}

\author{
Nishan Sakalasooriya \\ Department of Geography, University of Kelaniya, Kelaniya, Sri Lanka \\ Email: sakalasooriyanp@yahoo.com
}

How to cite this paper: Sakalasooriya, N. (2021). Conceptual Analysis of Sustainability and Sustainable Development. Open Jour nal of Social Sciences, 9, 396-414. https://doi.org/10.4236/jss.2021.93026

Received: February 8, 2021

Accepted: March 26, 2021

Published: March 29, 2021

Copyright (c) 2021 by author(s) and Scientific Research Publishing Inc. This work is licensed under the Creative Commons Attribution International License (CC BY 4.0).

http://creativecommons.org/licenses/by/4.0/ (c) (i) Open Access

\begin{abstract}
Understanding contemporary issues of social-ecological systems in environmentally sensitive areas is very complicated and requires careful and extensive research. The approach of "sustainability" is highly applicable to this task because it demands both social and ecological perspectives and it projects contemporary practices into the future. The World Commission on Environment and Development (1987) defined sustainable development as "the use of environment and resources to meet the needs of the present without compromising the ability of future generations to meet their own needs". This reiterates Karl Marx' suggestion that people make their own history, built on the past, and it becomes their future. In this sense, what we do today is the future of human society. The ultimate objective of this article is to discuss the concepts of sustainability and sustainable development which helps to generate new knowledge by creating a framework for sustainable development in environmentally sensitive areas of Sri Lanka. To achieve this objective, it is essential to employ a multifaceted and multidimensional methodology.
\end{abstract}

\section{Keywords}

Sustainability, Sustainable Development

\section{Introduction}

"Men make their own history, but they do not make it as they please, they do not make it under self-selected circumstances, but under circumstances existing already, given and transmitted from the past. The tradition of all dead generations weighs like a nightmare on the brains of the living." Karl Marx (1852).

Eighteenth Brumaire of Louis Bonaparte. The main objective of this article is to be refining the two concepts, sustainability and sustainable development because this is very significant to fulfill the objectives of study on "Developing a 
sustainable development framework for environmentally sensitive areas. This article is based on the literature review of the above-mentioned study. It is very difficult to define the concept and application of "sustainability". There is no universally accepted definition for the term because it is a multifaceted concept, changing through time and space. In general, its simple meaning is the "capacity to endure", but the meaning varies with subject discipline and fields of use. Within the last few decades, "sustainability" has emerged as a sub discipline, particularly in fields of physical and social science, because it has been widely used in problem solving and decision-making processes.

\section{Defining Sustainability}

Robert Engelmen (2013), president of the Worldwatch Institute expressed this conundrum well: "We live today in an age of sustainability, a cacophonous profusion of uses of the word 'sustainability' to mean anything from environmentally better to cool. The original meaning of the adjective is capable of being maintained in existence without interruption or diminution-goes back to the ancient Romans." The idea of "sustainability" is not new. It was part of the traditions and cultural norms of indigenous societies all over the world since their origin. The present-day concept of sustainability was introduced in 1972 by the United Nations Conference on Human Environment.

According to this perspective, the meaning of sustainability implies maintaining the capacity of ecological systems, to support and enhance the quality of social systems. Sustaining this capacity requires analysis and understanding of feedbacks and, more generally, the dynamics of the interrelations between ecological systems and social systems (Berkes, Colding, \& Folke, 2003; Van der Leeuw, 2000). For this reason, I use the concept of "social-ecological systems" throughout this study. Cumming (2008) and Holling (2001, 2003) have defined social-ecological systems as the complex systems which incorporate of any kind of human societies, economic systems, ecosystems and their interactions. They argue that studies of social-ecological systems must consider both human communities and natural resources, and their modification by human actions through time. The primary domain and heart of the social-ecological theory is not only explaining the feedback from human action to the biophysical environment but also the biophysical environmental responses to human actions (Waltner, Toews, Kay, and Lister, 2008). In this study, I use the term "sustainability" to mean the equitable, ethical and efficient use of natural resources for fulfilling the needs of current and future generations of human beings and enhancing their wellbeing.

Sustainability is a continual process and not an end product. The dynamic process requires adaptive capacity of social and ecological systems. Sustainability implies maintaining the capacity of ecological systems, to support and enhance the quality of social systems. Sustaining this capacity requires analysis and understanding of feedbacks and, more general, the dynamics of the interactions between ecological systems and social systems (Berkes, Colding and Folke, 2003, 
Van der Leeuw, 2000).

Political economist, Elinor Ostrom ${ }^{1}$, argued that long term sustainability of a social-ecological system depends on rules matching the attributes of the resource system, resource units, and users of resources. The initial set of rules, regulations, policies and strategies should be established by those who use the resources of a social-ecological system, or by the government with a high level of user-participation. Without user-input, long-term sustainability may not be achieved (Ostrom, 2009).

The word "sustainability" originally came from the Latin word called "sustinere" this means "to hold". Dictionary definitions of sustainability have in common the sense of "maintaining", "supporting", "enduring" or similar meanings. After publication of the report of the Brundtland Commission, "Our Common Future", in 1987, this term, "sustainability" has commonly been paired with the concept of development, (Onions, 1964; WCED, 1987). The three pillars (or 3E's) of Economy, Social Equity, and Environment were introduced by the World Summit on Social Development of United Nations held in 2005 (United Nations General Assembly, 2005). This concept is illustrated in Figure 1 (Forestry Commission of Great Britain, 2009). The 3Es concept has been widely used as common ground for sustainability standards and environmental certification systems by various institutions and organizations, to protect the natural environment of the Earth for future generations (Manning et al., 2011; Reinecke et al., 2012; SAI Platform, 2010).

As shown in Figure 1, the economy and social equity of a community depend on the biophysical environment. Economy exists within an economic system in which people interact, ideally, creating social equity. It is very clear that while economy is not everything. Everything (including economy, social system, and equity) depend on the environment. This is the focal point of the concept of sustainability, that all members of society, from the household to the global community must be taken into consideration in any kind of decision-making process intended to enhance present and future human wellbeing. Sustainable communities should recognize the limits and the carrying capacity ${ }^{2}$ of the natural, social and built systems upon which they depend. The key question which any kind of sustainable development planning process must address is "are we using this resource faster than it can be renewed?".

When understanding and formulating the sustainable development framework for a community, there are considerable areas to clarify, such as the ability to endure within the system, the important things and processes to be sustained by the community in the system, and the actual needs, requirements, and wishes ${ }^{1}$ Elinor Lin Ostrom (1933-2012) was an American political economist whose work was associated with the New Institutional Economics and the resurgence of political economy. In 2009, she shared the Nobel Memorial Prize in Economic Sciences with Oliver E. Williamson for her analysis of economic governance, especially the commons.

${ }^{2}$ The carrying capacity of a biological species in an environment is the maximum population size of the species that the environment can sustain indefinitely, given the food, habitat, water and other necessities available in. 


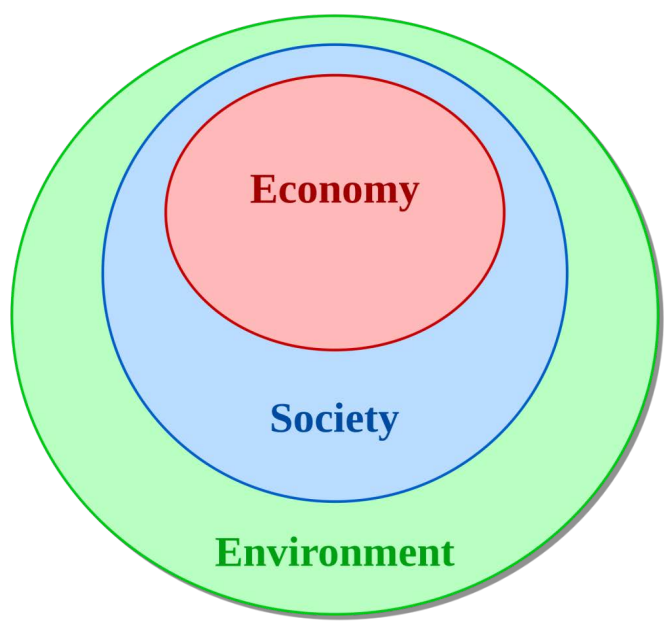

Figure 1. Three pillars of sustainability. Source: Forestry Commission of Great Britain. (2009) Sustainability, http://www.forestry.gov.uk/forestry/edik-59fmzf: Retrieved on: 09.12.2013.

of people in the systems. The process must consider the ecological wholeness and the capacity to recover the biological environment, the actual relationships among the so-called 3E's: Environmental resilience, Economic vitality, and social Equity.

The context of sustainability can be studied and managed through many scales of time and space and in many contexts of environmental, social and economic organization (Millennium Ecosystem Assessment Report, 2003). Millennium Ecosystem Assessment Report (2003) argues that, basically, sustainability of human wellbeing ranges from the total carrying capacity of the biophysical environment of the Earth, to the sustainability of economic sectors from the national level, to individuals. Daniel Botkin says that "We see a landscape that is always in flux, changing over many scales of time and space" (Kates, 2011).

Destruction of the relationship between natural resources and the processes of the biophysical environment of the Earth and humanly-handled activities is a major driver of the human impact on social-ecological systems at many levels. Both natural and human resources are essential to develop the wellbeing of human life through time and space. All kinds of achievement of people, as individuals, communities, nations or the entire global population, depend in very complex and complicated ways on the natural resources used to maintain their and future generations' livelihoods. Whether the natural resources are renewable or not, the scale of human activities relate to the carrying capacity, and the process of sustainability should be long-lasting and address long-term maintenance of the three pillars of sustainability (Dalal-Clayton and Bass, 2009). This study pays attention to the sustainability of the relationship between natural resources and human activities of three selected social-ecological systems in the environmentally sensitive areas of Sabaragamuwa Province in Sri Lanka.

The ecosystems of the earth are the vital resources for human development through time and space at any level, present and future. There are two major 
approaches in managing the human impact on ecosystem services: environmental management and management of resource consumption. The environmental management ${ }^{3}$ approach is based largely on information gained from educated professionals in many fields of Earth Science, Environmental Science, Conservation Biology and Geography. Management of consumption of resources is based largely on information gained from professionals in development. This study uses both approaches because both are essential to maintain sustainable social ecological systems.

The sustainability of a community interfaces with economics through the voluntary trade consequences of economic activity, therefore moving towards sustainability is not only a social challenge but also a political one (Cumming, 2008). Some political considerations include international and national law, urban planning and transport, local and individual lifestyles and ethical consumerism. Many forms of sustainable ways of living have been suggested, from controlled living conditions, such as eco-villages, eco-municipalities and sustainable cities, to reappraising work practices, such as using permaculture, green building, sustainable agriculture, or developing new technologies that reduce the consumption of resources. This study will examine government laws and regulations, and development policies and strategies, and their applicability to enhance the sustainability of communities in the three environmentally sensitive areas.

In the continual process of history, social-ecological systems have changed from simple to complex. From the earliest civilizations to the present they have gone from ecologically-dominated to human-dominated systems (Beddoea et al., 2009). This historical process has been characterized by the increased regional success of a particular society, followed by crises that were either resolved, producing sustainability, or not, leading to decline (Beddoea et al., 2009). Before the agricultural revolution, people used very simple technology to fulfill their basic needs. They may have altered the natural composition of plant and animal communities in early human history by, for example, using fire or the desire for specific foods. After the agricultural revolution, 8000 and 10,000 years ago, agrarian communities emerged which depended largely on their environment and the creation of a "structure of permanence" (Clarke, 1977).

In the $18^{\text {th }}$ and $19^{\text {th }}$ Centuries, the industrial revolution led to an increase in the use of fossil fuels to generate additional energy for increasing the efficiency of human activities. At the beginning, it was limited to the western countries but gradually spread to all the parts of world. Coal was used to power ever more efficient engines and, later, to generate electricity. Many scientific advances promoted human wellbeing by increasing life expectancy. For example, modern and safe sanitation systems and scientific advances in western medical sciences have provided protection from many diseases and epidemics (Meadows et al., 1972; Turner, 2008).

In the mid-20th Century, some environmental movements, scientific research-

${ }^{3}$ Some scholars say that it cannot be managed but people can change the biophysical environment and biophysical environment response to those changes. 
ers, authors, and organizations began to point out the environmental costs for achieving human benefits in many ways. In the late 20th Century, environmental problems expanded from the local to global scale. The 1973 and 1979 energy crises demonstrated the extent to which the global community had become dependent on non-renewable energy resources. At present in the $21^{\text {st }}$ Century, there are many controversial environmental issues, from the global to local level, such as global warming, environmental changes, floods, landslides, and droughts. These backgrounds have opened the doors towards sustainable development at any level (Meadows, Meadows, \& Randers et al., 1972; WCED, 1987; Turner, 2008; Cumming, 2009; Maser, 2013).

To reiterate, in this study, I define "sustainability" as the equitable, ethical and efficient use of natural resources for fulfilling the needs of current and future generations of human beings and enhancing their wellbeing.

\section{Conceptual Challenges of Sustainability}

There are conceptual challenges in applying the concept of "sustainability". No matter what object of sustainability is measured; there is a range of time across which sustainability is not achievable. Even a sustainable system eventually succumbs to entropy, asteroid collisions or other astronomical cataclysms. A universal truth in science and philosophy is that nothing is permanent in a physical sense. Accordingly, social ecological systems cannot be sustainable for indefinite periods of time. Even in the short term, definitions of sustainability are problematic only insofar as they move from theory to practice (Durant, Fiorino, and O’Leary, 2004, Eisner, 2007; Rosenbaum 2008; Vig \& Michael, 2006). However, within the relatively short time frames in which policy or decision makers operate, the goals of sustainability cease to appear paradoxical because of applying the concept to policy making presents conceptual and moral hazards (Mazmanian and Kraft, 2009).

In the face of these challenges, it is important that sustainability be understood less as an object and more as a process. Folke and Kabeger (1991) state "It is not meaningful to measure the absolute sustainability of a society at any point in time". According to them, there is not a climax or an endpoint of the sustainability process. According to the second law of thermodynamics, sustainability as permanence is not an option (Folke and Kabeger, 1991; Ukaga, Okechukwu, Maser, Chris, Reichenbach, \& Michael, 2013).

\section{Capitalist Crisis and Socialist Sustainability}

In the $21^{\text {st }}$ Century, there have been a growing number of innovative research studies in such areas as political ecology, environmental history and ecological economics to address the social-environment relationship at multiple spatial and temporal scales (Sheppard et al., 2009; Maser, 2013, Robbins, 2012). These multidisciplinary works have pointed out the inevitability to address difference, context, scale, and the social and environmental systems that connect places to each other. These approaches help policy planners, law makers, academics, prac- 
titioners and the general public to think about social-ecological relations. Pepper (1993) explains the relationship between political philosophies and environmentalism. He argues that the environmental policy of a country reflects its political philosophy. However, it is also critical to understand the complex interactions of biophysical environments and communities, and the ways in which they are continually coproducing each other through their mutual interactions at multiple scales (Holling 2001, 2003, Sheppard et al., 2009; Maser, 2013; Cumming, 2008).

Blaikie and Brookfield (1987) brought to light crucial issues of land degradation and society, examining the relationship between poverty and land degradation, with three major conclusions. First, land degradation causes political, economic, and ecological marginality and land degradation is both a cause and a result of social marginalization. Second, the pressure of production on land resources is transmitted to the environment through social relations or pressure of deprivation. Third, one person's land degradation is another's soil fertility.

This analysis requires a radical critique of population pressure on resources in the view of environment, conservation, and development of a community. Little and Horowitz (1987) developed the "regional political ecology" approach, focusing on the producer and ecological pressure in a particular geographic location. Using case studies from Africa, Asia and Latin America, they demonstrated the usefulness of case-specific data to test theoretical models of resource use and land degradation.

Most post-independence development efforts of developing countries, including Sri Lanka, have failed because they were designed according to western development models that communities failed to adopt. Central Bank of Sri Lan$\mathrm{ka}$ (1989) pointed out this situation as follows:

"This top down approach demotivated ordinary people, whose energies most needed to be mobilized in the development effort... The strategy, after independence, failed because it was based on poorly adapted foreign models. The vision was couched in the idiom of modernization... In recent years, however many elements of this vision have been challenged. Alternative paths have been proposed. They give primacy to agricultural development, and emphasize not only prices, markets and private sector activities but also capacity building, grass roots participation, decentralization and sound environmental practices... the time has come to put them fully into practice" (Central Bank of Sri Lanka, 1989).

Peet and Watts (2000) express skepticism about such statements by the World Bank. They argue that "failed modernization, alternative visions, grass roots participation, people power, and environmental sustainability: these are not in a vocabulary typically associated with the most influential advocate of global capitalist development." Further, Peet and Watts raise vital questions such as: could the World Bank approach really have embraced the popular energies of "ordinary people" in the name of sustainable development alternatives? 
Peet and Watts (2000) examine the history of development discourse since the industrial revolution, in four historical phases: First Industrial revolutions, Classical imperialism, Growth to Crisis and the contemporary period, demonstrating not only transformations in discourse, but also concomitant changes in the role of the state, civil society and the market.

In 1972, the United Nations, in recognition of the collapsing global environmental equilibrium at the Stockholm conference, appointed a committee to study and make a report of environmental issues at the global level. In 1987, the Brundtland commission published "Our Common Future", emphasizing the need for sustainable development practices. This document pointed out three critical areas of the development process: economic, society and environment. Consequently, lots of organizations and researchers have made efforts to find the roots of the issues and to find the answers for environmental issues.

Capitalist attempts to find solutions for failures are generally within the capitalist framework and include such solutions as energy management, increasing efficiency, recycling, alternative energy sources, and signing agreements to reduce carbon emissions. Capitalist victories for owners of capital create devastation for "ordinary people". Consequently, Marxists and Neo-Marxists developed another argument about environmental degradation from the local to global level.

According to Marxism, three of capitalism's basic features make it anti-ecological (Williams, 2010). Those three features are: 1) An imperative for constant expansion of economy as a whole, 2) The drive for profit in each economic unit and 3) A built-in focus on the short term. Williams (2010) explains the issues of capitalism as follows:

“...Marx captured capitalism's general drive for expansion with his classic definition of the root purpose of the system-the self-expansion" of capital, symbolized as $\mathrm{M}-\mathrm{C}-\mathrm{M}$. The process begin with money, $\mathrm{M}$, which is turned into a commodity $C$, to be sold on the market for $M$, where $M$ is money than the original $M$. The cycle then repeats on an enlarged basis with a larger starting pot of capital" (Williams, 2010).

In this continual process, social-ecological systems collapse in many ways and the capitalist system struggles to survive. Consequently, the capitalist system is on an unsustainable "treadmill of production" with overconsumption of materials and energy. If any part of the capitalist economy is not expanding its economic growth rate more than $2 \%$, social systems collapse, with increasing unemployment rates, company lay-offs, government tax income failures, and budget crises. The capitalist system is a problem in itself.

One of the main problems of the capitalist approach to environmental issues is its inherent separation of economy and environment, or the need to evaluate environmental strictly according to its market values and influence. Stephen Schneider, Stanford biologist and climate scientist, illustrates this with his analysis of capitalist attitudes on climate change.

"Most conventional economists thought that even this gargantuan climate 
change, equivalent to the scale of the change from the ice age to an interglacial epoch in a hundred years, rather than thousands of years, would have only a few percent impact on the world economy. In essence, they accept the paradigm that society is almost independent of nature" (Schneider, as quoted in Foster, 2009)

The crisis of capitalist societies has led some to argue that in the advancement of science and technology is found the solutions for all issues made by capitalism. In this crisis, they do not calculate or evaluate the environmental cost. When the environmental costs are ignored, then the sustainability of social systems collapses. Istvan Meszaros explaining this problem:

“... to say that science and technology can solve all our problems in the long run is worse than believing in witchcraft; for it tendentiously ignores the devastating social embeddedness of present-day science and technology. In this respect, too the issue is not whether or not we use science and technology for solving our problem, for obviously we must, but whether or not we succeed in radically changing their direction which is at present narrowly determined and circumscribed by the self-perpetuating needs of profit maximization" (Meszaros, quoted in Foster, 2009).

The above arguments explain the profit maximization process of capitalism and the consequent generation of unsustainability in society, economy and the biophysical environment. In a nut shell, capitalism has shown and proved its failures to ensure sustainability in capitalist societies. Even in the so-called socialist countries, there are many failures in sustainability in development process. This study focuses on three village areas in Sabaragamuwa province, where the main livelihood is agriculture. There are two types of agricultural systems: commercial crops, such as tea, rubber, pepper; and intensive subsistence agriculture, such as paddy, and vegetable production. The land use pattern has varied over time according to the price fluctuation in the market, destabilizing not only the economy but also social and environmental systems. As Kovel Joel (2007) explains:

"the dependence of the cultivation of particular agricultural products upon fluctuations of market prices, and the continual changes in this cultivation with these price fluctuations, the whole spirit of capitalist production, which is directed toward the immediate gain of money, are in contradictions to agriculture, which has to minister to the entire range of permanent necessities of life required by the chain of successive generations" (Joel, 2007).

Capitalism depends on scarcity. Where there is no scarcity, scarcity is created in order to maximize profit through artificial competition. An example of this is the exacerbation of soil depletion. The proposed solution to decreasing soil fertility is chemical fertilizers, creating profit for fertilizer industries. Farmers need more harvest to earn more money to purchase fertilizer, further destroying the natural fertility of the soil system and contaminating it with chemicals harmful 
for farmers and consumers of these agricultural products. Resulting illnesses, specially unknown etiology such as kidney disease in the North Central Province of Sri Lanka, require medications and medical intervention, again producing profit for the pharmaceutical and medical industries. People tend to believe that this continual process is unstoppable.

Marxist and Neo-Marxists argue that the process is stoppable because everything changes, evolves, and dies out, and new species come into being. Williams (2010) suggests:

"to live sustainability must mean at the very least to attempt to maintain and stabilize current climatic conditions as human civilization has come to know them. We can achieve this in part by a necessary and urgent switch to renewable energy and through minimizing our use of resources and waste production based on the principle of a long term view of interdependence with nature" (Williams, 2010).

Marxism, neo Marxism, and other socialist movements, argue that only a socialist future holds out the hope of a sustainable society and it is essential to organize for a system change of capitalism. In communist countries environmental degradation has been the result of failure to practice appropriate technology and/ or over usage of natural resources in the development process. For example, in the Chernobyl disaster, hundreds of people were killed, land and animals were contaminated, and the impact continues in the contemporary generation. Therefore, even without a capitalist economy, environmental sustainability is not guaranteed.

\section{Measuring Sustainability}

Measuring sustainability is not an easy task, but one of the initial attempts to express human impact mathematically was developed in the 1970s and is called the "I PAT" formula. This formulation attempts to explain human consumption and affluence, in terms of three components: population numbers, levels of affluence, and impact per unit of resource use, which is termed "technology" (Ehrlich \& Holden, 1971). The equation is:

$$
I=P \times A \times T,
$$

where " $P$ " = Environmental impact, " $P$ " = Population, " $A$ " = Affluence and " $T$ " = Technology.

I believe that this formula has use for measuring the sustainability between the countries. On the other hand, the definitions of the factors in this formula are poorly defined. Therefore, to measure the sustainability of regions within a country, a community, or a particular social-ecological system, it is necessary to use more specific indicators to measure sustainability.

Measuring and developing indicators of measurement for sustainability is complex. It requires assessment of not only biophysical, social and economic domains, but also various combinations of these. There have been many at- 
tempts to construct indicators, benchmarks, audits, sustainability standards and certification systems, indices and accounting, as well as assessment, appraisal and other reporting systems. These have been applied over a wide range of spatial and temporal. Such analyses require region and time specific, rather than broad, sustainable indicators. I examine below sustainability indices currently in use and explain my choice of indicators for my analysis.

\section{Environmental Sustainability Index}

The Environmental Sustainability Index (ESI) was developed by Yale University's Center for Environmental Law and Policy in collaboration with Columbia University's Center for International Earth Science Information Network (CIESIN), and the World Economic Forum. Using ESI they publish an annual report, ranking the countries from 1999 through 2005. Since 2006, they have been using a new index, called Environmental Performance Index (EPI), to rank the environmental performance of countries (Yale Center for Environmental Law \& Policy/Center for International Earth Science Information Network at Columbia University, 2013). The annual report of the EPI was published in 2012 and ranked 132 countries on 22 environmental performance indicators under ten policy categories as mentioned below:

1) Environmental Health

2) Water (effects on human health)

3) Pollution (effects on human health)

4) Air Pollution (ecosystem effects)

5) Water Resources (ecosystem effects)

6) Biodiversity and Habitat

7) Forests

8) Fisheries

9) Agriculture

10) Climate change Source: http://epi.yale.edu/sites/default/files/downloads/2012-epi-full-report 0.pdf

According to the 2012 ESI report, Switzerland ranked highest and Iraq lowest. Sri Lanka was ranked $55^{\text {th }}$. While these indicators were created for the purpose of ranking, I found them useful as measures of sustainability in my case study villages, and therefore use some ESI health and ecosystem vitality indicators.

\section{Community Sustainable Indicators}

To sustain peoples' wellbeing in a region, it is essential to move from 'clouds to concrete' and develop practical assessment tools. Constructing and developing relevant, scientific, and reliable indicators to measure sustainability are vital to building sustainable communities in a particular region. Indicators thus need to be tailored to fit diverse communities, and to monitor and evaluate changes in direction or intensity, in regular and methodical ways. These indicators must measure regional and community-level capacity in ways that do not sacrifice 
important opportunities for future generations.

Indicators must be integrative measures of economic, social, and ecological health, designed to gauge a community's systematic balance and resilience over a long period of time. An example of this is the work of Hampel (1996), who has developed 16 indicators to measure the sustainability of a community:

- Percent of workforce covered by health insurance

- Greenhouse gas emissions per capita

- Number of domestic violence calls to police

- Number of community gardens

- Land filled solid waste (tons per year)

- Percent of households that can afford median-priced house

- Water use and wastewater flows (Gallons/day/persons)

- Net growth in livable wage jobs

- Graduation rate by race and ethnicity

- Energy consumption (BTU per capita)

- Voter turnout in municipal elections

- Pounds of toxic produced and released per year

- Dollar value of repairs or replacement needed in infrastructure investment

- Homeownership rate

- Number of endangered and threatened species

- Community Volunteerism by age group

Source: Hempel (1996).

Hempel argues that when we measure the sustainability of communities, it is necessary to specify the exact targets of the measurement. Consequently Hempel's system goes on to classify community indicators into General, Quality of Life and finally, the corresponding Sustainability Indicator. For example, a General indicator is "Job Growth Rate". The corresponding Quality of Life indicator is "Unemployment" and the Sustainability Indicator is "Per cent of new jobs paying a livable wage". Hempel's indicators are a useful model and are predominantly applicable to urban communities.

The Ontario Round Table of Environment and Economy (ORTEE) assembled a Sustainable Communities Working Group that developed eleven principles defining "sustainable communities". These principles are broad in scope and primarily support incorporation of environmental understanding into policy-making. Examples include "Minimizes harm to the natural environment" and "Makes best use of local efforts and resources". To make these very general principles useful and practical, indicators developed for a specific community around each principle would be useful.

Source: ORTEE (Ontario Round Table of Environment and Economy). (1994).

http://placersustain.org/community/content/sustainability-principles-ontar

io-round -table-environment-and-economy: Retrieved on 11.01.2014

"Ecological footprint analysis" is a common approach for developing and applying sustainability indicators at the community level. Wackernagel and Rees 
(1996) describe this approach:

“...This analysis conceives of footprint as accounting tools for calculating human impacts in terms of the land and water areas appropriated for energy and resource consumption and for waste disposal. An ecological footprint is a measure of the load placed on the biosphere by a given population. Footprints are therefore proportional to a community's combined population and per capita consumption of resources (Wackernagel and Rees, 1996).

While the ecological footprint is a valuable aid to explaining sustainability analysis, it requires methods, definitions and variables specific to a given community in order to be a pragmatic means for measuring sustainability.

All the indicators which explained above help me to understand about the measuring sustainability and developing the sustainable indicator. In this study, 28 indicators were developed for measure the sustainability of the social-ecological systems of my study villages.

\section{Rationale of Sustainable Development}

A vast literature on sustainable development has given rise to many definitions since the classic formulation of the Brundtland report, "Our Common Future" (WCED, 1987). This report's widely accepted definition of sustainable development is "development that meets the needs of the present without compromising the ability of future generations to meet their own needs" (WCED, 1987). The Brundtland Report definition focused on two key concepts. As Williams (2010) explains, these are:

1) "The concept of "needs", in particular the essential needs of the world's poor to which overriding priority should be given, and

2) The concept of limitations imposed by the estate of technology and social organization on the environments' ability to meet present and future needs."

The International Union for Conservation of Nature (IUCN) has a similar definition: "Sustainable development is a commitment to "improving the quality of human life while living within the carrying capacity of supporting ecosystems".

After the publication of the Brundtland Report on the world environmental crisis, academicians and practitioners in development fields began to discuss practical development approaches to advance human wellbeing in a sustainable manner. The development discourse became somewhat mainstreamed and in the process, global environmental problems and institutions overshadowed local ones, and poverty in the Global South became the identified problem and cause of environmental degradation, rather than consumption in the Global North and the ways in which it produces poverty.

In ensuing discussions, many important arguments came to light and many reasonable complaints were launched about double standards, of new rules for current poor and peripheral locations that reinforce development discourse while erecting barriers to achieving development. Examples abound. First World coun- 
tries suggested that tropical countries such as Brazil and Indonesia conserve their rainforests as sources of biodiversity, sequesters of carbon, and producers of oxygen for the global good. However, these suggestions were coming from the very nations that had been central to industrialization and wealth creation in Europe and North America (Escobar, 1995; Sneddon, 2000). Developed countries are more concerned about recycling waste than about reducing their consumption pattern. On the other hand, many countries, including developed nations, have turned to protecting threatened biophysical environments, by establishing national parks, reservations, environmentally sensitive zones, fragile areas, and programs to protect threatened species. Such protection laws and policies often badly affect poor communities, whose livelihood patterns and lifestyles are linked with their surrounding biophysical environment (Sheppard et al., 2009).

"In 2003, Asia-Pacific and Africa were using less than world average per person bio-capacity, while the EU and North America had crossed the threshold for high human development. No region, nor the world as a whole, met both criteria for sustainable development. Cuba alone did, based on the data it reports to the United Nations." (WWF, 2006: p. 19)

\section{Applications of Sustainable Development}

The complexities of environment-societal related issues are well illustrated in many environmental movements in the Third World. Such movements differ from mainstream environmentalism or sustainable development because they are generally couched in terms of defending not only particular environments, but also the lives and livelihoods that those environments sustain. Some poor communities in the developing world derive their livelihood from the forests, fields, and waters around them, thus sustainability is intimately related to rights of communal ownership, collectively shared ways of knowing, cultural economy, religious rituals, and freedom from externally imposed program that seek to promote someone else's vision of how to conserve or develop the environments they depend upon. These movements may be described as 'environmental livelihood" movements (Sheppard et al., 2009). It is essential to understand this in the policy or decision-making process. The sustainability and equity of local livelihood systems are interdependent and interlinked with other dynamic social and biophysical systems, and may involve hierarchies along multiple dimensions, for example, gender, class, and caste.

Consider the variety of values that humans derive from the environment in a particular place. Sheppered et al. (2009) have categorized different types of values, they are mentioned below.

1) Intrinsic existence value: of the biophysical world and all of its inhabitants.

2) Recreational or scenic value: of places, or the ways that they give meaning to life.

3) Life support Value: the "natural economy" of the biophysical world reproducing the conditions necessary to sustain life. 
4) Commodity value: environment as a source resource that are appropriated to be sold, including both renewable resources (e.g., water, land, forests) and nonrenewable resources (e.g., oil, minerals).

5) Use Value: resources (renewable and nonrenewable) appropriated from the local ecosystem for direct consumption Sink value: the environment as a "free disposal site for wastes.

\section{Conclusion}

Definitions, including the official definition of the Brundtland Report, concentrate on absolute and chronic poverty and development, with concern for the state of the ecological systems and processes of biophysical environment, giving attention mainly two kinds of equity:

1) Intra-generational equity which concerns the equity between haves and have-nots;

2) Intergenerational equity, which concerns the equity between present and future generations.

Conservation or management of components of the biophysical environment towards a sustainable future is very complex because the relationship between social systems and ecological systems is very complex. Therefore, law makers and policy planners who work with sustainable development must pay attention to complexity. Modern scientific explanation teaches us to understand the biophysical environment as assembled systems of biological and physical things, ranging from subatomic particles to plants and animal, the continents, oceans and atmosphere. This complexity works according to a set of biophysical laws and processes, such as the laws of physics and chemistry, the hydrologic cycle, the nutrient cycle, and atmospheric cycles, operating at many temporal scales, ranging from nanoseconds to millennia, and spatial scales, ranging from the infinitesimal to the global.

These critical views and ideas were frequently expressed at the 2002 World Summit on Sustainable Development and helped to convince some observers that sustainable development had become a public relations cloak for corporate globalization. Some public movements define community sustainability in way that highlights relationships between local quality of life and changes in land use, population, consumption, civic participation, and commitment to inter-temporal equity.

On the other hand, discouraged by the lack of global integration in the management of social ecological systems, environmental activists have embraced the sustainable community idea as a good way to encourage such integration at the local level. Practicing what Wildavsky (1979) called a "strategic retreat from objectives", many environmentalists pointed out and embraced the 1980s slogan "Think globally; act Locally", thereby framing and attacking an increasing number of regional, national, and global environmental problems at the local level. Such thinking received a boost at the 1992 Earth Summit, when participating 
nations agreed to implement Agenda 21 Plans for both local and national level sustainable development.

Some of the scholars and researchers have spotted the dilemma of economic development at many levels. There were debates over relativism and positivism, community and individual, carrying capacity of the environment and perpetual economic growth, religions and secularism, and socialism and capitalism (Cobb \& John, 1994; Cobb \& John, 1995; Cobb, Ted, \& Jonathan, 1995). These scholars have clearly explained that the rise of neoliberal economic theory is a self-serving materialism and positivist science in an unwaveringly pro-growth paradigm of the modern economic world. Furthermore, they assured that the influence of this process is not only for social systems but also biophysical environment systems. Finally they expressed the importance of a new way to conceptualize and measure economic progress of societies.

Ukaga et al. (2013) have pointed out that;

"The ISEW (Indicator of Sustainable Economic Welfare) and GPI (Genuine Progress Indicator) were the results of these discussions. Over the last four decades in United States of America GPI considerably lower than the GDP because GPI considers the income inequality, social malaise, and degradation of natural environment (Ukaga, Maser, and Reichenbach, 2013).

To sustain the deliberative democracy and development in progressive democratic economics, 07 characteristics have been identified by:

1) Preference transformation

2) Orientation to the public good

3) Rational argument

4) Consensus

5) Equality

6) Inclusiveness

7) Transparency

Considering all these definitions and argument, Maser (2013) says that "development" means personal and social transformation to a higher level of consciousness and a greater responsibility toward the next generation. 'Sustainability' is the act whereby one generation saves options by passing them to the next, and so on (Maser, 2013: Editor's note, Land-use planning for Sustainable Development). Understanding the above explanations and arguments, the first definition, introduced by WCED report, is used for defining the "sustainable development" is still reputed and widely accepted. These definitions have been applied for the study of developing a sustainable development framework for environmentally sensitive areas of central environmental sensitive area of Sri Lan$\mathrm{ka}$. The finding and the sustainable development framework will be presented in the next article of this author.

\section{Conflicts of Interest}

The author declares no conflicts of interest regarding the publication of this paper. 


\section{References}

Beddoea, R., Costanzaa, R., Farleya, J., Garza, E., Kent, J., Kubiszewski, I., Martinez, L., McCowen, T., Murphy, K., Myers, N., Ogden, Z., Stapleton, K., \& Woodward, J. (2009). Overcoming Systemic Roadblocks to Sustainability: The Evolutionary Redesign of Worldviews, Institutions, and Technologies. Proceedings of the National Academy of Sciences of the United States of America, 106, 2483-2489. https://doi.org/10.1073/pnas.0812570106

Berkes, F., Colding, J., \& Folke, C. (2003). Navigating Social-Ecological Systems: Building Resilience for Complexity and Change. New York, NY: Cambridge University Press.

Blaikie, P., \& Brookfield, H. (1987). Land Degradation and Society, New York, NY: Methuen.

Central Bank of Sri Lanka. (1989). Annual Reports. Colombo: Department of Census and Statistics. Colombo.

Clarke, W. C. (1977). The Structure of Permanence: The Relevance of Self-Subsistence Communities for World Ecosystem Management. In T. P. Bayliss-Smith, \& R. G. Feachem (Eds.), Subsistence and Survival: Rural Ecology in the Pacific (pp. 363-384). London: Academic Press. https://doi.org/10.1016/B978-0-12-083250-7.50017-0

Cobb, C, W., \& John, B. C. (1995). Human Economy Center. The Green National Product: A Proposed Index of Sustainable Economic Welfare. Lenhem, MD: University Press of America.

Cobb, C. W., \& John, B. C. (1994). The Green National Product: A Proposed Index of Sustainable Economic Welfare (pp. 251). Lenhem, MD: University Press of America.

Cobb, C. W., Ted, H., \& Jonathan, R. (1995). If the GDP Is Up, Why Is America down? Atlantic Monthly.

Cumming, G. S. (2008). Spatial Resilience in Social-Ecological Systems. New York, NY: Springer.

Dalal-Clayton, B., \& Bass, S. (2009). The Challenges of Environmental Mainstreaming. Issues Paper, London: International Institute for Environment and Development. http://www.environmental-mainstreaming.org

Durent, R. F., Fiorino, D. J., \& O’Leary, R. (2004). Environmental Governance Reconsidered: Challenges, Choices, and Opportunities. Cambridge, MA: MIT Press.

Ehrlich, P. R., \& Holden, J. P. (1971). Impact of Population Growth. Science, 171, $1212-$ 1217. https://doi.org/10.1126/science.171.3977.1212

Eisner, M. (2007). Governing the Environment: The Transformation of Environmental Regulation. Boulder, CO: Lynne Rienner.

Engelman, R. (2013). Beyond Sustainable Instate of the World: Is Sustainability Still Possible? Washington DC: Island Press.

Escobar, A. (1995). Encountering Development. Princeton, NJ: Princeton University Press.

Folke, C., \& Kabeger, T. (1991). Recent Trends in Linking the Natural Environment and the Economy. In C. Folke, \& T. Kabeger (Eds.), Linking the Recent Trends in Linking the Natural Environment and the Economy: Essays from Eco-Eco Group (pp. 273-300). Dordrecht: Springer. https://doi.org/10.1007/978-94-017-6406-3 14

Forestry Commission of Great Britain. (2009) Sustainability. http://www.forestry.gov.uk/forestry/edik-59fmzf

Foster, J. B. (2009) The Ecological Revolution: Making Peace with the Planet. New York, NY: Monthly Review Press.

Hampel, L. C. (1996). Environmental Governance: The Global Challenge. Washington 
DC: Island Press.

Holling, C. S. (2001). Understanding the Complexity of Economic, Ecological and Social Systems. Ecosystems, 4, 390-405. https://doi.org/10.1007/s10021-001-0101-5

Holling, C. S. (2003). Foreword: The Backloop to Sustainability. In F. Berkes, J. Colding, \& F. Carl (Eds), Navigating Social-Ecological Systems: Building Resilience for Complexity and Change (pp. Xv-Xxii). New York, NY: Cambridge University Press. https://doi.org/10.1017/CBO9780511541957.002

Joel, K. (2007). The Enemy of Nature: The End of Capitalism or End of the World? New York, NY: Zed Books.

Kates, R. W. (2011). From the Unity of Nature to Sustainability Science: Ideas and Practice. CID Working Paper No. 218, Cambridge, MA: Center for International Development, Harvard University.

Little, P., \& Horowitz, M. (1987). Lands at Risk in the Third World. Boulder, CO: Westview Press.

Manning, S., Boons, F., Von Hagen, O., \& Reinecke, J. (2011). National Contexts Matter: The Co-Evolution of Sustainability Standards in Global Value Chains. Ecological Economics, 83, 197-209. https://doi.org/10.1016/j.ecolecon.2011.08.029

Marx, K. (1852). Eighteenth Brumaire of Louis Bonaparte. http://www.marxists.org/archive/marx/works/1852/18th-brumaire/ch01.htm

Maser, C. (2013). Decision Making for a Sustainable Environment: A Systematic Approach. Abingdon-on-Thames: Taylor \& Francis Group.

Mazmanian, D. A., \& Kraft, M. E. (2009). The Three Epochs of the Environmental Movement, in Toward Sustainable Communities: Transition and Transformations in Environmental Policy (2nd ed.). Cambridge, MA: MIT Press.

https://doi.org/10.7551/mitpress/9780262134927.003.0001

Meadows, D. H., Meadows, D. L., Randers, J., \& Behrens, W. W. (1972). The Limits to Growth: A Report for the Club of Rome's Project on the Predicament of Mankind. New York, NY: Universe Books. https://doi.org/10.1349/ddlp.1

Onions, C. T. (1964). The Shorter Oxford English Dictionary. Oxford: Clarendon Press.

ORTEE (Ontario Round Table of Environment and Economy). (1994). http://www.envstudiesyork.ca/public/law/ebr-93.htm

Ostrom, E. (2009). A General Framework for Analyzing Sustainability of Social-Ecological Syatems. Science, 325, 419-422. https://doi.org/10.1126/science.1172133

Peet, R., \& Watts, M. J. (2000). Liberation Ecologies: Environment, Development, Social Movements. USA: Routledge.

Pepper, D. (1993). Eco-Socialism: From Deep Ecology to Social Justice. London: Routledge.

Reinecke, J., Manning, S., \& Von, H. O. (2012). The Emergence of a Standards Market: Multiplicity of Sustainability Standards in the Global Coffee Industry. Organization Studies, 33, 791-814. https://doi.org/10.1177/0170840612443629

Robbins, P. (2012). Political Ecology: A Critical Introduction (2nd ed). New York, NY: John Wiley \& Sons, Ltd.

Rosenbaum, W. A. (2008). Environmental Politics and Policy (7th ed). Washington DC: CQ Press.

SAI Platform (2010). Sustainability Indicators. Sustainable Agricultural Initiative.

Sheppard, E. P., Philip W., Faust, R. D., \& Nagar, R. (2009). A World of Difference: Encountering and Contesting Development. New York, NY: The Guilford Press. 
Sneddon, C. S. (2000). Sustainability in Ecological Economics, Ecology and Livelihoods: A Review. Progress in Human Geography, 24, 521-549. https://doi.org/10.1191/030913200100189076

Turner, G. (2008). A Comparison of "The Limits to Growth" with Thirty Years of Reality. Canberra: Commonwealth Scientific and Industrial Research Organization (CSIRO).

Ukaga, O., Maser, C., \& Reichenbach, M. (2013). Sustainable Development: Principles, Frameworks and Case Studies. New York, NY: Tayalor and Francis Group.

United Nations General Assembly (2005). 2005 World Summit Outcome, Resolution A/60/1.

Vander Leeuw, S. E. (2000). Land Degradation as a Socionatural Process. In R. J. McIntosh, J. A. Tainter, \& S. K. McIntosh (Eds.), The Way the Wind Blows: Climate, History and Human Action (pp. 190-220). New York, NY: Columbia University Press.

Vig, N. J., \& Michael, E. K. (2006). Environmental Policy: New Directions for the 21st century (6th ed.). Washington DC: CQ Press.

Wackernagel, M., \& Rees, W. (1996). Our Ecological Footprint: Reducing Human Impact on the Earth. Philadelphia, PA: New Society Publishers.

Waltner-Toews, D., Kay, J. J., \& Lister, N. M. (2008). The Ecosystem Approach: Uncertainty and Managing for Sustainability. New York, NY: Columbia University Press

WCED (World Commission on Environment and Development). (1987). Our Common Future. New York, NY: Oxford University Press.

Wildavsky, A. (1979). Politics of the Budgetary Process. New York, NY: Sage Publication.

Williams, C. (2010). Ecology and Socialism: Solutions to Capitalist Ecological Crisis, Chicago, IL: Heymarket Books.

WWF (World Wild Fund) (2006). Living Planet Report 2006. Global Footprint Network. World Wide Fund for Nature, Zoological Society of London.

Yale Center for Environmental Law \& Policy/Center for International Earth Science Information Network at Columbia University. (2013) 2012 Environmental Performance Index Report.

http://epi.yale.edu/sites/default/files/downloads/2012-epi-full-report 0.pdf 